Corresponding author: hrehm@ partners.org

(C) 2016 Rehm This article is distributed under the terms of the Creative Commons Attribution-NonCommercial License, which permits reuse and redistribution, except for commercial purposes, provided that the original author and source are credited.

Published by Cold Spring Harbor Laboratory Press

doi: 10.1101/mcs.a001545

Competing Interest Statement

The author has declared no competing interest.

\section{Rapid access to genetic discoveries underlying human disease}

\author{
Heidi L. Rehm
}

Brigham and Women's Hospital and Harvard Medical School, Boston, Massachusetts 02115, USA; Partners Healthcare Laboratory for Molecular Medicine, Cambridge, Massachusetts 02139, USA; and Broad Institute of MIT and Harvard, Cambridge, Massachusetts 02142, USA

This month Cold Spring Harbor Molecular Case Studies unveils a new article type, Rapid Communications, for the dissemination of novel genetic variants and/or novel phenotypes in known genes discovered in patients from genetic and genomic sequencing. With the regular identification of novel variants in patients with rare diseases, an efficient mechanism to define the spectrum of variation and the range of clinical presentations associated with previously identified genes is needed.

Rapid Communications allow reporting of novel variants alongside a description of the case presentation and a table of detailed clinical features and, if available, a description of disease progression and any treatment responses. The evidence for the interpretation of the variant(s) is presented and discussed, including functional studies if performed, to inform the level of understanding of the pathogenicity of the variant(s) and includes implications for management or treatment if relevant.

The streamlined and structured format of the Rapid Communication article type allows consistency of reporting and a more rapid review process. Variants must also be submitted to a publicly accessible database (such as ClinVar) to enable ease of access of this information to the community.

In this issue, Yu et al. present two probands with compound heterozygous mutations in SPG11, a gene previously implicated in hereditary spastic paraplegias (HSP). Whole-genome sequencing was deployed to determine HSP subtype. The authors discovered a novel maternally inherited splice variant and a previously reported paternally inherited nonsense variant in SPG11, annotated as pathogenic and likely pathogenic, respectively, and supporting a spastic paraplegia type 11 diagnosis.

In addition to contributing the novel SPG11 splice variant to NCBI's ClinVar database, this Rapid Communication enriches the public knowledgebase by presenting additional clinical information alongside a discussion of the variants and their interpretation.

The editors hope this new format will accelerate the dissemination of novel variants implicated in disease and also encourage the community to deposit their findings into public databases such as ClinVar for wider community use. Following with the aims of the journal, all published articles, including Rapid Communication articles, are open access and available to every clinician and researcher online, with the goal of advancing our knowledge of genetic disease in the age of precision medicine. 


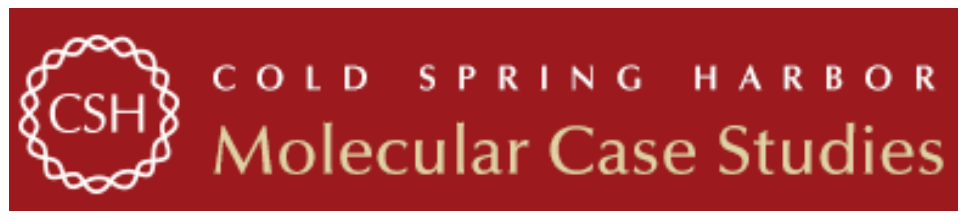

\section{Rapid access to genetic discoveries underlying human disease}

Heidi L. Rehm

Cold Spring Harb Mol Case Stud 2016, 2: a001545

Access the most recent version at doi: $10.1101 /$ mcs.a001545

\begin{tabular}{cl}
\hline License & $\begin{array}{l}\text { This article is distributed under the terms of the Creative Commons } \\
\text { Attribution-NonCommercial License, which permits reuse and redistribution, except } \\
\text { for commercial purposes, provided that the original author and source are credited. }\end{array}$ \\
$\begin{array}{c}\text { Email Alerting } \\
\text { Service }\end{array}$ & $\begin{array}{l}\text { Receive free email alerts when new articles cite this article - sign up in the box at the } \\
\text { top right corner of the article or click here. }\end{array}$ \\
\hline
\end{tabular}

